\title{
THE EFFECT OF EMPOWERMENT, WORK MOTIVATION AND PROCEDURAL JUSTICE TOWARD ORGANIZATIONAL CITIZENSHIP BEHAVIOR (OCB) OF TEACHERS OF REGROUPING PUBLIC ELEMENTARY SCHOOLS (SDN) IN SOUTH JAKARTA
}

\author{
Yanthy Herawaty Purnama Pangaribuan \\ Jakata State University, YanthyHerawaty mp15s3@mahasiswa.unj.ac.id \\ Mukhneri Mukhtar, \\ Jakarta State University, mukhneri@unj.ac.id \\ Bedjo Sujanto, \\ Jakarta State University, bedjo1951@gmail.com
}

\section{ABSTRACT}

The research is to see the effect of empowerment, work motivation, and procedural justice towards Organizational Citizenship Behavior (OCB) of teachers of Regrouping Elementary Schools (SDN) in South Jakarta . The sample of this research is 269 Civil Servants teachers of regrouping SDN in South Jakarta selected at random. The approach used is quantitative with the survey method The tool used is the multiple regression and the path analysis of the results of this study shows that the five hypotheses are accepted or no hypothesis is rejected. The results of this research conclude that empowerment has a direct positive effect toward $\mathrm{OCB}$, work motivation has a direct positive effect toward OCB, procedural justice has a direct positive effect toward $\mathrm{OCB}$, empowerment has a direct positive effect toward work motivation, and empowerment has a direct positive effect to procedural justice.

Keywords: empowerment, work motivation, and procedural justice, and Organizational Citizenship Behavior (OCB)

\section{INTRODUCTION}

According to Colquitt, Lepine, and Wesson (2013: 43-440)," OCB is defined as voluntary employee activities that may or maynot be rewardd but contribute to the organization by improving the overal qulaity of the setting in which work takes place" A successful organization not only depends on individual skills and expertise yet also on the empowerment of members, employee work motivation and equal treatment that leads to productive Organizational Citizenship Behavior (OCB) behavior and is able to adapt to challenges and achieve organizational vision and mission. The purpose of this study is to see the effect of empowerment, work motivation, and procedural justice towards Organizational Citizenship Behavior (OCB) of teachers of Regrouping Elementary Schools (SDN) in South Jakarta

\section{Literature Review}

Organization Citizenship Behavior (OCB)

OCB is part of the science of organizational behavior, that is work behavior which is usually not seen or not taken into account. These behaviors, for example, are cooperating actively, helping each other, actively participating and demonstrating initiatives and using work time effectively with organizational progress goals. OCB is defined by Schermerhorn (2010:336) as follows: "Organizational citizenship behavior is a willingness to go beyond the call of duty or go to the extra mile in one's work." Schermerhorn proposes the OCB as a willingness to carry out work beyond its obligations by making every effort beyond its organizational expectations or in other words OCB is a behavior of someone who is willing to do something beyond what has been described as his job even though it has no reward.

\section{Empowerment}

Empowerment is a management process that utilizes all people in an organization to play an active role in accordance with their respective capabilities, authorities and responsibilities. The implication of empowerment is the effectiveness of teamwork due to the feeling of being part of the organization. Newstrom (2011:207-208) supports the opinion by giving this explanation: Empowerment is any process that provides greater autonomy to employees' throughout the sharing of relevant information and the provision of control over factors affecting job performance. Five broad approaches to empowerment have been suggested (1) Helping employees achieve job mastery (giving proper training, coaching and guided experience that will result in initial success, (2) Allowing more control (giving them discretion over job performance and then holding them accountable for outcome), (3) Providing succesfull role modes (allowing them to observe peers who already perform successfully on the job), (4) Using social reinforcement and persuasion (giving praise, encouragement, and verbal feedback 
designed to raise self confidence), (5) Giving emotional support providing reduction of stress and anxiety through better role definition, task assistance caring. The above opinion explains that empowerment is a process that gives employees greater power through a variety of relevant information and the provision of access or factors that affect performance. Several empowerment approaches, among others are (1) helping employees achieve job mastery (providing the right training, coaching, and experience that will result in success), (2) provide more control (gives greater freedom and then assigns responsibility for the results they are working on), (3) set a successful example (enabling them to see their colleagues who have already succeeded in their work, (4) using social reinforcement and trust (giving praise, encouragement, and verbal feedback designed to increase confidence), and (5) providing emotional support (providing stress and anxiety reduction through better role giving, guidance and attention).

\section{Work motivation}

Motivation is a psychological process in a person that is influenced by various factors. Motivation comes from the Latin word "movere" meaning encouragement or move. Gary and Saks (2011:146) define motivation as follows: "motivation as the extent to which persistent effort is directed toward goal." Motivation is the persistence of one's effort to a goal. Motivation relates to desire or urge within a person to perform a certain action and maintain the behavior to achieve the desired goal.

\section{Procedural Justice}

The concept of organizational justice is often incorporated in the study of organization and management because every individual in the organization requires that he be fairly needed. Therefore, fair procedures describe good organizational capacity because procedural justice is concerned with making and implementing decisions referring to fair processes within the organization.

According to Schermenhorn (2010:117), "procedural justice is the degree to which the rules and procedures specified by policies are properly followed in all cases to which they are applied". The degree to which the rules and procedures specified by policies are properly followed in all cases to which they are applied.

Mc Shane and Von Glinow(2015:151) describe that, "procedural justice, on the other hand, refers to fairness of the procedures used to decide the distribution of resources." Procedural justice, on the other hand, refers to fairness of the procedures used to decide the distribution of resources. This opinion is reinforced by Lutnas (2011: 172) in a similar statement that "procedural justice is concerned with the fairness of the procedure used to make a decision." Procedural justice is concerned with the fairness of the procedure used to make a decision.

\section{THE THEORITICAL MODEL}

Hypoteses:

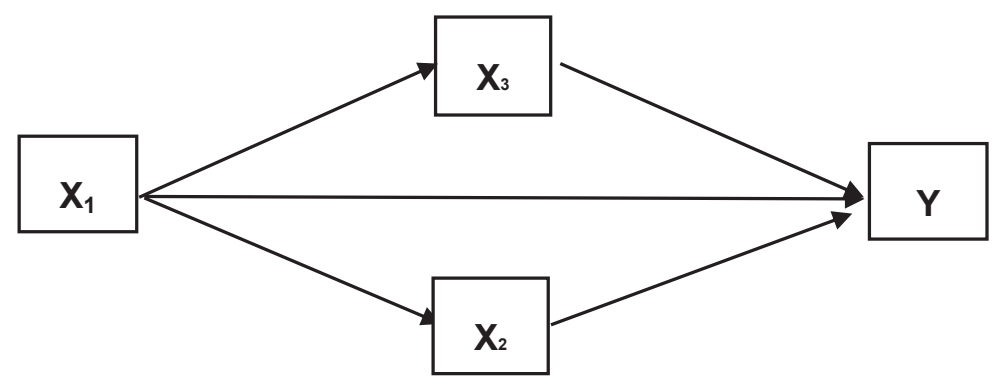

1. Empowerment has a direct positive effect toward OCB.

2. Work motivation has a direct positive effect toward OCB.

3. Procedural justice has a direct positive effect toward OCB

4. Empowerment has a direct positive effect toward work motivation.

5. Empowerment has a direct positive effect to procedural justice. 


\section{RESEARCH METHOD}

This research uses the quantitative approach through the survey method. Survey research involves collecting data to test hypotheses or answering questions about people's opinions on some topics or issues. Surveys are instruments for collecting data explaining one or more specific population characteristics. Hypothesis testing of this research uses the path analysis technique with constellation model between variables consisting of 4 variables, namely: exogenous variables are Empowerment, Work Motivation, Procedural Justice, and endogenous variable which is OCB.

Population in this research is civil servant educatos/ teachers (year 2015) at regrouping SDN in South Jakarta. Samples were taken using the simple random sampling technique based on the sampling technique formula from Slovin, which is:

$n=\frac{N}{N \cdot d^{2}+1}$

$n \quad$ : number of samples

$N \quad$ : number of population

$d^{2} \quad$ : error tolerance limit (error tolerance) set is 5\% which means it has an accuracy of $95 \%$

By using the formula, the following is obtained:

$$
n=\frac{826}{826 \cdot(0,05)^{2}+1}=\frac{826}{3,065}=269
$$

The influence between variables in this study was analyzed by the using path analysis technique (path analysis). This analytical technique is believed to have the power to test the influence between variables based on theoretical formulas and not to derive the cause and effect theory. The consequence of using this technique is the necessity of using causal thinking which is a prerequisite in path analysis.

\section{RESEARCH RESULTS AND DISCUSSION}

The path calculation is divided into 3 (three) sub-structures ie: (1) effect of empowerment $\left(X_{1}\right)$, work motivation $\left(X_{2}\right)$, and procedural justice $\left(X_{3}\right)$, toward OCB $(Y)$. (2) Effect of empowerment $\left(X_{1}\right)$ toward work motivation $\left(X_{2}\right)$. (3) Effect of empowerment $\left(X_{1}\right)$ toward procedural justice $\left(X_{3}\right)$.

1. The calculation of path coefficients of substructure 1 (one)

The calculation result of substructure 1 (one) can be seen in Table 1.1 below:

Tabel 1.1 Path Coefficients of Substructure 1 (one)

Coefficients $^{\mathrm{a}}$

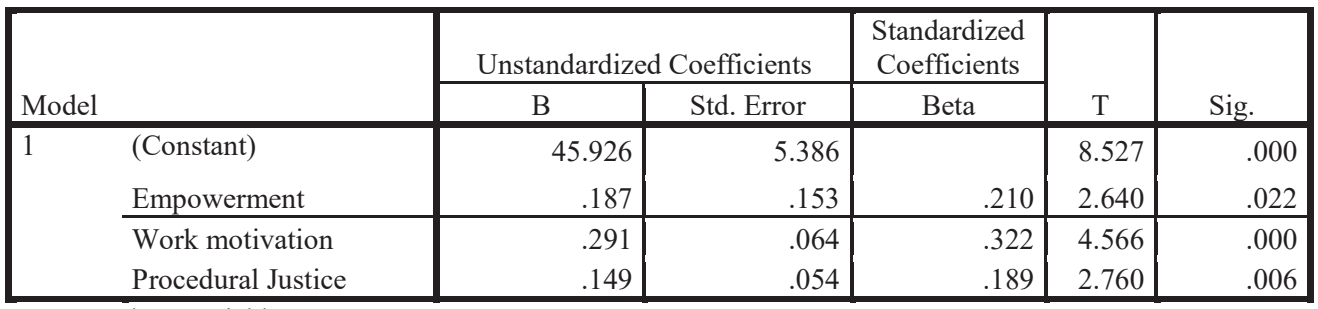

a. Dependent Variable: OCB

Based on the calculation results in Table 1.1 above, the research hypothesis test can further be explained as follows:

a) Direct Positive Effect of Empowerment $\left(\mathrm{X}_{1}\right)$ toward OCB (Y)

To test that Empowerment $\left(\mathrm{X}_{1}\right)$ has a direct positive effect on $\mathrm{OCB}(\mathrm{Y})$, the tested hypothesis is as follows:

$\mathrm{H}_{\mathrm{o}}: \beta_{\mathrm{y} 1} \leq 0$

$\mathrm{H}_{1}: \beta_{\mathrm{yl}}>0$

b) Direct Positive Effect of Work Motivation $\left(\mathrm{X}_{2}\right)$ toward OCB $(\mathrm{Y})$

To test that Work Motivation $\left(\mathrm{X}_{2}\right)$ has a direct positive effect toward $\mathrm{OCB}(\mathrm{Y})$ the tested hypothesis is as follows:

$\mathrm{H}_{\mathrm{o}}: \beta_{\mathrm{y} 2} \leq 0$

$\mathrm{H}_{1}: \beta_{\mathrm{y} 2}>0$

c) Direct Positive Effect of Procedural Justice $\left(\mathrm{X}_{3}\right)$ toward OCB $(\mathrm{Y})$

To test that Procedural Justice $\left(\mathrm{X}_{3}\right)$ has a direct positive effect toward $\mathrm{OCB}(\mathrm{Y})$ the tested hypothesis is as follows:

$\mathrm{H}_{\mathrm{o}}: \beta_{\mathrm{y} 3} \leq 0$

$\mathrm{H}_{1}: \beta_{\mathrm{y} 3}>0$

2. The calculation of path coefficients of substructure 2 (two)

The calculation result of substructure 2 (two) can be seen in Table 1.2 below: 
Tabel 1.2 Path Coefficients of substructure 2 (two)

Coefficients $^{\mathrm{a}}$

\begin{tabular}{|c|c|c|c|c|c|}
\hline \multirow[b]{2}{*}{ Model } & \multicolumn{2}{|c|}{ Unstandardized Coefficients } & \multirow{2}{*}{$\begin{array}{c}\begin{array}{c}\text { Standardized } \\
\text { Coefficients }\end{array} \\
\text { Beta }\end{array}$} & \multirow[b]{2}{*}{$\mathrm{T}$} & \multirow[b]{2}{*}{ Sig. } \\
\hline & $\mathrm{B}$ & Std. Error & & & \\
\hline $1 \quad$ (Constant) & 51.065 & 5.129 & & 9.956 & .000 \\
\hline Empowerment & .465 & .052 & .484 & 9.032 & .000 \\
\hline
\end{tabular}

a. Dependent Variable: Work motivation as follows:

To test that Empowerment $\left(\mathrm{X}_{1}\right)$ has a direct positive effect toward Work Motivation $\left(\mathrm{X}_{2}\right)$, the tested hypothesis is

Ho : $\beta_{21} \leq 0$

H1 : $\beta_{21}>0$

Based on the calculation result, path coefficient $p_{21}=0.484$ is obtained with the value of $t_{\text {count }}=9.032$, while $t_{\text {table }}=$ $1.969(\alpha=0.05)$ and because $t_{\text {count }}>t_{\text {table }}(\alpha=0.05)$, Ho is rejected, meaning the path coefficient is significant. The results of this hypothesis testing shows that Empowerment (X1) has a direct positive effect toward Work Motivation (X2). Or in other words, it can be stated that there is a direct positive effect of Empowerment $\left(\mathrm{X}_{1}\right)$ toward Work Motivation $\left(\mathrm{X}_{2}\right)$.

3. The calculation of path coefficient of substructure 3 (three)

The calculation result of substructure 3 (three) can be seen in Table 1.3 below

Table 1.3 Path Coefficients of Substructure 3 (three) Coefficients ${ }^{\mathrm{a}}$

\begin{tabular}{|c|c|c|c|c|c|}
\hline \multirow[b]{2}{*}{ Model } & \multicolumn{2}{|c|}{ Unstandardized Coefficients } & \multirow{2}{*}{$\begin{array}{c}\text { Standardized } \\
\text { Coefficients }\end{array}$} & \multirow[b]{2}{*}{$\mathrm{T}$} & \multirow[b]{2}{*}{ Sig. } \\
\hline & $\mathrm{B}$ & Std. Error & & & \\
\hline $1 \quad$ (Constant) & 50.634 & 6.057 & & 8.359 & .000 \\
\hline Empowerment & .482 & .061 & .436 & 7.921 & .000 \\
\hline
\end{tabular}

a. Dependent Variable: Procedural Justice

To test whether Empowerment $\left(\mathrm{X}_{1}\right)$ has a direct positive effect toward Procedural Justice $\left(\mathrm{X}_{3}\right)$, the tested hypothesis is as follows:

$\mathrm{H}_{\mathrm{o}}: \beta_{31} \leq 0$

$\mathrm{H}_{1}: \beta_{31}>0$

Based on the calculation result, path coefficient $p_{31}=0.436$ is obtained with the value of $t_{\text {count }}=7.921$, while $t_{\text {table }}=$ $1.969(\alpha=0.05)$ and because $t_{\text {count }}>t_{\text {table }}(\alpha=0.05)$, Ho is rejected, meaning that the path coefficient is significant. The results of this hypothesis testing shows that Empowerment $\left(\mathrm{X}_{1}\right)$ has a direct positive effect toward Procedural Justice $\left(\mathrm{X}_{3}\right)$. Or in other words it can be stated that there is a direct positive effect of Empowerment $\left(\mathrm{X}_{1}\right)$ toward Procedural Justice $\left(\mathrm{X}_{3}\right)$.

The results toward the decision on all hypotheses can be seen in the following constellations:

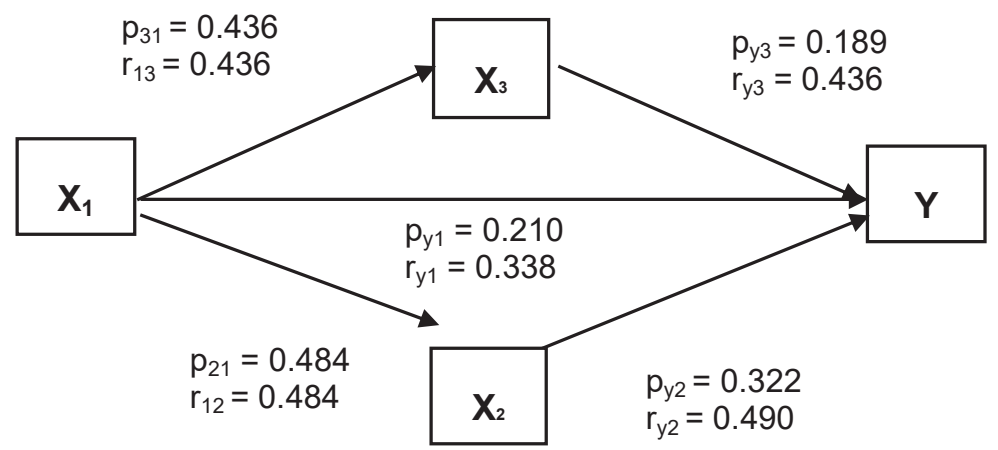

Figure 1.1 Empirical Model of Strucutral Relationships Among the Variables Based on the Analysis of Path Result 


\section{RESULT DISCUSSION}

\section{Empowering toward $\mathrm{OCB}$}

The results in this study shows on the calculation result, path coefficient pyl $=0.210$ is obtained with value of $\mathrm{t}_{\text {count }}=$ 2.640, while $t_{\text {table }}=1.969(\alpha=0.05)$ because $t_{\text {count }}>t_{\text {table }}(\alpha=0.05)$, Ho is rejected, meaning the path coefficient is significantindicate that empowerment has a direct positive effect on OCB. It shows It indicates indicate that empowerment has a direct positive effect on OCB. Empowerment is an effective buffer against self-problems because there are important resources for individuals such as autonomy, participation in decision making and competence, and because empowerment helps them cope with stressful events.

\section{Work Motivation toward OCB}

Based on the calculation result, path coefficient $p_{\mathrm{y} 2}=0.322$ is obtained with the value of $t_{\text {count }}=4.566$, while $t_{\text {table }}=$ $1.969(\alpha=0.05)$ because $t_{\text {count }}>t_{\text {table }}(\alpha=0.05)$, Ho is rejected, meaning the path coefficient is significant. According to Robbins, Judge (2013:224) explains, "in organizations that focus more on behaviors, following your motivation to be a good citizen can help to accomplish your career goals". In organizations that focus more on behavior, the presence of the motivation to become a good citizen of the organizations can help achieve one's career goals. It shows high work motivation will increase the sense of responsibility in every OCB conducted.

\section{Procedural Justice toward $\mathrm{OCB}$}

Based on the calculation result, path coefficient $p_{\mathrm{y} 3}=0.189$ is obtained with the value of $t_{\text {count }}=2.760$, while $t_{\text {table }}=$ $1.969(\alpha=0.05)$ because $t_{\text {count }}>t_{\text {table }}(\alpha=0.05)$, Ho is rejected, meaning the path coefficient is significant. The results of this hypothesis testing shows that Procedural Justice $\left(\mathrm{X}_{3}\right)$ has a direct positive effect toward OCB (Y). Or in other words, it can be stated that there is a direct positive effect of Procedural Justice $\left(\mathrm{X}_{3}\right)$ toward OCB $(\mathrm{Y})$. . This suggests that good Procedural Justice between leaders and subordinates or otherwise creates a good and proper OCB for teachers. Besides, the application of good procedural justice will increase the sense of responsibility in every OCB conducted.

Fred Luthans (2011:173) that, "finally, a recent study moved to the level of overall justice climate (procedural, informational, and interpersonal) and found it related to various work outcomes (commitment, satisfaction, and citizenship behavior)".

\section{Empowerment toward Work Motivation}

The results of this study indicate that empowerment directly has a positive effect on work motivation. These show that good and effective empowerment can also improve work motivation for teachers. This condition can occur if the school management realizes and understands the importance of empowerment in improving work motivation. In addition, the application of good empowerment will increase the sense of responsibility in every activity undertaken.

Demirci dan Erbas (2010: 146) state that, "Empowerment also gives growth support to its employees through career planning, rewards and welfare, and by employing counseling, motivation, and appraisals techniques, uses social reinforcement and persuasion in the organization.Motivation is the real effort and energy employees put intothe daily work to complete the task or work."

Based on the description above and the empirical verification and the results of the research conducted, it is found that empowerment directly has a positive effect on interpersonal communication.

\section{Empowerment toward Procedural Justice}

The results in this study indicate that empowerment has a direct positive effect on Procedural Justice. This suggests that good and effective empowerment can improve good procedural justice for teachers as well. This condition can occur when the school management realizes and understands the importance of empowerment in improving Procedural Justice. Besides, the application of good empowerment will increase the sense of responsibility for teachers to motivate good work as well.

Individuals are part of a team, and teams are part of an organization. The success of an organization depends not only on the ability and skill of an individual but also the ability and excellence of the other members. Changes occur when development is done. Employee empowerment is a critical determinant of successful perceptions of justice, especially distributive and procedural justice, as mentioned by Wai Kwan Lau (2014:72)that:

Employee's participation (Empowerement) is a critical success factor for justice perception, especially for distributive and procedural justice. It is hoped that the present investigation will spark additional forays into the relation between leadership styles and organizational justice.

Empowerment is proven to increase employees' perceptions in compliance with existing procedures. In this case, it means that empowerment has an impact on procedural justice, as Kyuu Eun Lee (2014:1)in his research mentioned that: this study shows that, as the nurses' perception of organizational justice becomes greater, empowerment and organizational commitment are heightened while turnover intention goes down. Improvements: Therefore, for effective hospital human resources management, nursing organizations and hospital organizations must change the design and system of the organization so that the nurses' perception of organizational justice will become greater. 
This study shows that, the nurses' perception of organizational justice becomes greater, empowerment and organizational commitment increases, and employee discharge decreases. Improvements: Therefore, for effective management of human resources in hospitals, nursing organizations and hospital organizations must change the organization's design and systems so that nurses' perceptions of organizational justice will be greater.

Based on the above description and empirical verification as well as the results of the research conducted, it is found that empowerment has a direct positive effect on Procedural Justice.

\section{CONCLUSION}

Based on the results of the analysis and discussion that have been described in the previous explanation, the conclusions of this study are as follows: (1) Empowerment directly has a positive effect on OCB. This means that the empowerment of teachers can improve OCB for the better. (2) Work Motivation has a direct positive effect on OCB. It is that high motivation of teachers can improve OCB for the better. (3) Procedural Justice has a direct positive effect on OCB. That means that good procedural justice can improve teachers' OCB. (4) Empowerment has a direct positive effect on work motivation. This means that the empowerment of teachers can increase teachers' work motivation to become better. (5) Empowerment has a direct positive effect on procedural justice. This means that the empowerment of teachers can improve teachers' procedural justice.

\section{IMPLICATIONS}

The implications of the results obtained from this study can be explained as follows: (1) Empowerment has a direct positive effect on OCB. The implication is to carry out mutual relationships of respect, appreciation, and mutual cooperation. This will have an impact on improving teachers' performance and school effectiveness by understanding the OCB behavior of teachers to be utilized by the school leadership. (2) Work Motivation has a direct positive effect on OCB. The implication of teachers who possess high work motivation bring out positive effect nt only for teachers themsleves, but also the school enviroment as well. high motivation produces strong determination, persistence, and resilience. (3) Procedural Justice has a direct positive effect on OCB. The implications are to involve all elements of the school in policy, to do proper justice in terms of formal procedures, award allocation, interpersonal treatment when making policies or implementing regulations, and to communicate effectively so as to influence perceptions of fair treatment that encourage all members to behave in OCB. (4) Empowerment has a direct positive effect on work motivation. The implications are continuous coaching to cultivate work motivation through activities, direct direction, incentives and opportunities for scientific activities, self-development, and motivational traning, which should be considered for implementation. (5) Empowerment has a direct positive effect on Procedural Justice. The implications are facilitating teachers for self-development, providing equal opportunities for all teachers to participate in all school activities and giving guidance to all school residents to do their jobs properly and maximally.

\section{BIBLIOGRAPHY}

DEMiRCi M. Kemal, Employee Empowerment and Its Effect on Organizational Performance, Sarajevo: 2nd International Symposium on Sustainable Development, 2010.

Fred Luthans, Organizational Behavior: An Evidence-Based Approach, 12th Edition USA: McGraw-Hill/Irwin, 2011.

Jason A Colquitt, Jeffery A Lepine, and Michael J Wesson, Organizational Behavior: improving Perfromance and Vommitmtne in the Workplace, New York: Mc Graw Hill,2013.

John R. Schermerhorn, Introduction to Management $10^{\text {th }}$ Edition ,Danver: John Willey and Sons, 2010

John W Newstorm, Organizational Behavior. Human Behavior at Work, New York: McGraw Hill Companies Inc, 2011

Gary Johns and Alan M Saks, Organizational Behaviour, Understanding and Managing Life at Work Eighth Edition, ,Canada: Pearson, 2011

Kyuu Eun Lee, "Influence of Perceived Organizational Justice on Empowerment, Organizational Commitment and Turnover Intention in the Hospital Nurses", Indian Journal of Science and Technology, Vol 9 (20), Korea: Kwandong University, 2014

Steven L. McShane dan Mary Ann Von Glinow, Organizational Behavior: Emerging Knowledge, Global Reality ,United States: McGraw-Hill, 2015

Wai-Kwan Lau, Employee's Participation: "A Critical Success Factor for Justice Perception under Different Leadership Styles", Journal of Management Policies and Practices, Vol. 2(4), December 2014, USA: American Research Institute for Policy Development. 